\title{
An Extraordinary Effect of Ether on the Polymerization of Methacrylates with Grignard Reagent in Toluene
}

\author{
Koichi Hatada, Koichi Ute, Tatsuki Kitayama, \\ and Mikiharu KAMACHI* \\ Department of Chemistry, Faculty of Engineering Science and \\ * Department of Macromolecular Science, Faculty of Science, \\ Osaka University, Toyonaka, Osaka 560, Japan
}

(Received October 8, 1983)

\begin{abstract}
KEY WORDS Grignard Reagent / Methyl Methacrylate / Ethyl Methacrylate / Effect of Ether / Stereospecific Polymerization / Syndiotactic Polymer / ESR / Propagating Active Species /
\end{abstract}

Many papers have been published on the polymerization of methacrylates by Grignard reagents. In these polymerization systems, there exist independent active centers of different reactivities and stereospecificities, whose proportions depend on the reaction conditions. ${ }^{1-6}$ The polymers usually become more syndiotactic as the ether component of the solvent mixture increases. ${ }^{1-3,5} \mathrm{~A}$ highly isotactic polymer was formed in toluene on using deetherated $\mathrm{C}_{6} \mathrm{H}_{5} \mathrm{MgBr}$ or $t-\mathrm{C}_{4} \mathrm{H}_{9} \mathrm{MgBr}$ as an initiator. ${ }^{4,7}$ This clearly indicates that the active center solvated with ether molecule is syndiotacticfavoring and the unsolvated center is isotacticfavoring. ${ }^{3)}$

In this work, it was found that the de-etherated $\mathrm{C}_{4} \mathrm{H}_{9} \mathrm{MgCl}$ or $\mathrm{C}_{4} \mathrm{H}_{9} \mathrm{MgBr}$ gave a highly syndiotactic poly(methyl methacrylate) (PMMA) in toluene, while a mixture of isotactic and syndiotactic polymers was formed in toluene in the presence of diethyl ether. An extraordinary effect of deetheration was also observed in the polymerization of ethyl, isopropyl, and $t$-butyl methacrylates with $\mathrm{C}_{4} \mathrm{H}_{9} \mathrm{MgCl}$. The formation of a mixture of isotactic and syndiotactic PMMAs with $\mathrm{C}_{4} \mathrm{H}_{9} \mathrm{MgCl}$ has already been reported by Inagaki and his coworkers. ${ }^{8}$

Butylmagnesium halides were prepared in diethyl ether from the corresponding butyl halide and magnesium. The concentration of Grignard reagent thus obtained was adjusted to $0.86 \mathrm{~mol} \mathrm{l}^{-1}$, and the solution was used as the initiator, which is described as " $\mathrm{BuMgX} / \mathrm{Et}_{2} \mathrm{O}$ " $(\mathrm{X}=\mathrm{Cl}$ or $\mathrm{Br})$.
The de-etheration of $\mathrm{BuMgX} / \mathrm{Et}_{2} \mathrm{O}$ was carried out by evaporating the solution under high vacuum, followed by redissolving the residue in toluene and evaporating the solvent again. The resulting white powder was suspended in toluene and used as the "de-etherated BuMgX." The powder dissolved completely in tetrahydrofuran- $d_{8}$ and the ${ }^{1} \mathrm{H}$ NMR spectrum of the solution indicated that the mole ratio of $\mathrm{Et}_{2} \mathrm{O}: \mathrm{BuMgX}$ was $0.10: 1.0$ for deetherated $\mathrm{BuMgCl}$ and $0.15: 1.0$ for de-etherated $\mathrm{BuMgBr}$. In further experiments, the white powder was redissolved in $\mathrm{Et}_{2} \mathrm{O}$. The titration of this solution by $s$-butanol, using 9,10-phenanthroline as an indicator ${ }^{9}$ confirmed that most of the BuMg-groups were active $(>99 \%)$. Also, the NMR spectrum was identical to that of $\mathrm{BuMgX} / \mathrm{Et}_{2} \mathrm{O}$. The polymerizations of MMA and $\mathrm{EMA}$ by the $\mathrm{BuMgCl} / \mathrm{Et}_{2} \mathrm{O}$, prepared from the de-etherated $\mathrm{BuMgCl}$ by the addition of $\mathrm{Et}_{2} \mathrm{O}$, brought about essentially the same results as when using the original $\mathrm{BuMgCl} / \mathrm{Et}_{2} \mathrm{O}$ (cf. Tables I and II). Thus, an irreversible change does not occur during the de-etheration procedure.

Polymerization was initiated by adding the monomer slowly to the initiator solution cooled to the polymerization temperature. The reaction vessel was then sealed off. The reaction was terminated by the addition of a small amount of methanol at the reaction temperature. Isolation of the polymer and oligomer was carried out as reported previously. ${ }^{10}$

Polymerization of methyl methacrylate (MMA) 


\section{K. HATADA et al.}

Table I. Polymerization of MMA with Grignard reagent in toluene at $-78^{\circ} \mathrm{C}$ for $24 \mathrm{~h}^{\mathrm{a}}$

\begin{tabular}{|c|c|c|c|c|c|c|}
\hline \multirow{3}{*}{ Initiator } & \multicolumn{5}{|c|}{ Polymer } & \multirow{3}{*}{$\begin{array}{c}\text { Oligomer } \\
\%\end{array}$} \\
\hline & \multirow{2}{*}{$\frac{\text { Yield }}{\%}$} & \multicolumn{3}{|c|}{ Tacticity $/ \%$} & \multirow{2}{*}{$M_{n}^{\mathrm{c}}$} & \\
\hline & & I & $\mathbf{H}$ & $\mathrm{S}$ & & \\
\hline $\mathrm{BuMgCl} / \mathrm{Et}_{2} \mathrm{O}$ & $49^{b}$ & 31 & 21 & 48 & 17600 & 18 \\
\hline $\mathrm{BuMgCl} / \mathrm{Et}_{2} \mathrm{O}^{d}$ & 1 & 10 & 15 & 75 & - & 16 \\
\hline De-etherated $\mathrm{BuMgCl}$ & 87 & 3 & 19 & 78 & 54700 & 11 \\
\hline $\mathrm{BuMgCl} / \mathrm{Et}_{2} \mathrm{O}^{\mathrm{e}}$ & 59 & 32 & 16 & 52 & - & 28 \\
\hline $\mathrm{BuMgBr} / \mathrm{Et}_{2} \mathrm{O}^{\mathrm{g}}$ & 6 & 32 & 12 & 56 & - & 12 \\
\hline De-etherated $\mathrm{BuMgBr}^{\mathrm{g}}$ & 90 & 4 & 21 & 75 & - & 10 \\
\hline$t-\mathrm{BuMgCl} / \mathrm{Et}_{2} \mathrm{O}^{\mathrm{g}}$ & 41 & 68 & 9 & 23 & - & 59 \\
\hline De-etherated $t$-BuMgCl $\mathrm{f}^{\mathrm{f}, \mathrm{g}}$ & 34 & 23 & 16 & 61 & - & 3 \\
\hline
\end{tabular}

a Monomer, $10 \mathrm{mmol}$; solvent, $10 \mathrm{ml}$; initiator, $1.0 \mathrm{mmol}$.

b By using a competitive adsorption method, ${ }^{8}$ the polymer was separated into isotactic $(46 \%)$ and syndiotactic $(54 \%)$ fractions, with tacticities of $\mathrm{I}: \mathrm{H}: \mathrm{S}=62: 13: 25$ and $\mathrm{I}: \mathrm{H}: \mathrm{S}=11: 24: 65$, respectively.

c Determined by GPC calibrating the chromatogram against standard polystyrene samples.

d Polymerization in THF.

e The initiator used in this run was prepared by the addition of a small amount of $\mathrm{Et}_{2} \mathrm{O}$ to the de-etherated $\mathrm{BuMgCl}$ $\left(\mathrm{Et}_{2} \mathrm{O}: \mathrm{BuMgCl}=10: 1\right)$.

f The de-etheration of $t$ - $\mathrm{BuMgCl} / \mathrm{Et}_{2} \mathrm{O}$ was unsuccessful by the procedure described in the text $\left(\mathrm{Et}_{2} \mathrm{O}: t-\mathrm{BuMgCl}=\right.$ $0.64: 1.0)$. Consequently the de-etheration of $t-\mathrm{BuMgCl}$ was carried out by evacuation at $100^{\circ} \mathrm{C}$ for $5 \mathrm{~h}\left(\mathrm{Et}_{2} \mathrm{O}: t-\right.$ $\mathrm{BuMgCl}=0.05: 1.0)$.

g Initiator $0.5 \mathrm{mmol}$.

Table II. Polymerization of ethyl methacrylate with $\mathrm{BuMgCl}$ in toluene at $-78^{\circ} \mathrm{C}$ for $24 \mathrm{~h}^{\mathrm{a}}$

\begin{tabular}{|c|c|c|c|c|c|c|c|c|c|c|}
\hline \multirow{3}{*}{ Initiator } & \multicolumn{5}{|c|}{$\mathrm{MeOH}$-soluble part } & \multicolumn{5}{|c|}{$\mathrm{MeOH}$-insoluble part } \\
\hline & \multirow{2}{*}{$\frac{\text { Yield }}{\%}$} & \multicolumn{3}{|c|}{ Tacticity $/ \%$} & \multirow{2}{*}{$M_{n}^{\mathrm{b}}$} & \multirow{2}{*}{$\frac{\text { Yield }}{\%}$} & \multicolumn{3}{|c|}{ Tacticity $/ \%$} & \multirow{2}{*}{$M_{n}^{\mathrm{b}}$} \\
\hline & & I & $\mathrm{H}$ & $\mathrm{S}$ & & & I & $\mathrm{H}$ & S & \\
\hline $\mathrm{BuMgCl} / \mathrm{Et}_{2} \mathrm{O}$ & $52^{\mathrm{c}}$ & 100 & 0 & 0 & 11700 & 0 & - & - & - & - \\
\hline De-etherated $\mathrm{BuMgCl}$ & 48 & 16 & 34 & 50 & 9400 & 50 & 0 & 26 & 74 & 73800 \\
\hline $\mathrm{BuMgCl} / \mathrm{Et}_{2} \mathrm{O}^{\mathrm{d}}$ & 60 & 100 & 0 & 0 & - & 0 & - & - & - & - \\
\hline
\end{tabular}

a Monomer, $10 \mathrm{mmol}$; solvent, $10 \mathrm{ml}$; initiator, $1.0 \mathrm{mmol}$.

${ }^{b}$ Determined by GPC.

c The polymer consisted of hexane-soluble $(9 \%)$ and -insoluble $(91 \%)$ parts.

d The initiator used in this run $(0.5 \mathrm{mmol})$ was prepared by the addition of a small amount of $\mathrm{Et}_{2} \mathrm{O}$ to the de-etherated $\mathrm{BuMgCl}\left(\mathrm{Et}_{2} \mathrm{O}: \mathrm{BuMgCl}=10: 1\right)$.

with $\mathrm{BuMgCl} / \mathrm{Et}_{2} \mathrm{O}$ and de-etherated $\mathrm{BuMgCl}$ were carried out in toluene at $-78^{\circ} \mathrm{C}$. The results are shown in Table I. Polymerization by $\mathrm{BuMgCl} / \mathrm{Et}_{2} \mathrm{O}$ gave a mixture of isotactic and syndiotactic polymers and methanol-soluble oligomer as reported by Inagaki et al. ${ }^{8}$ When the de-etherated $\mathrm{BuMgCl}$ was used as the initiator, a highly syndiotactic polymer was formed in high yield and the oligomer decreased in amount. This indicates that the amount of initiator consumed for the formation of polymer and oligomer decreased on using the de-etherated initiator. However, the rate of polymerization was 
higher with the de-etherated $\mathrm{BuMgCl}$ than by the $\mathrm{BuMgCl} / \mathrm{Et}_{2} \mathrm{O}$ initiator. Therefore, the activity of de-etherated $\mathrm{BuMgCl}$ should be higher than that of $\mathrm{BuMgCl} / \mathrm{Et}_{2} \mathrm{O}$. The ether component is of importance in determining the kinetics and stereospecificity of polymerization with the Grignard reagent; however, it usually enhances the formation of the syndiotactic polymer. ${ }^{1-3,5}$ Polymerization with $\mathrm{BuMgCl} / \mathrm{Et}_{2} \mathrm{O}$ in THF gave a syndiotactic polymer and an oligomer (Table I). In view of this the increase in the syndiotacticity upon the deetheration is an unexpected phenomenon. A similar effect of de-etheration was observed on the polymerization of MMA with $\mathrm{BuMgBr}$ and $t-\mathrm{BuMgCl}$, as shown in Table I.

The results of the polymerization of ethyl methacrylate (EMA) with $\mathrm{BuMgCl}$ in toluene at $-78^{\circ} \mathrm{C}$ are shown in Table II. PEMA obtained by $\mathrm{BuMgCl} /$ $\mathrm{Et}_{2} \mathrm{O}$ was completely soluble in methanol. When the polymer was fractionated by hexane, a highly isotactic and high molecular weight polymer was obtained as an insoluble fraction and an isotactic oligomer as a soluble fraction. Polymerization with the de-etherated initiator formed methanol-soluble and -insoluble fractions. Both fractions were found to be syndiotactic and the syndiotacticity of insoluble fraction was higher than that of soluble one. Formation of an isotactic polymer by $\mathrm{BuMgCl}$ / $\mathrm{Et}_{2} \mathrm{O}$ and a syndiotactic polymer by de-etherated $\mathrm{BuMgCl}$ was also observed in the polymerization of isopropyl and $t$-butyl methacrylates. ${ }^{11}$ These results indicate that the formation of a syndiotactic polymer by de-etherated Grignard reagent is a general trend in the polymerization of methacrylate.

The electron spin resonance (ESR) spectrum of the de-etherated $\mathrm{BuMgCl}-\mathrm{MMA}$ system showed 9 $(=5+4)$ lines ( $\mathrm{a}=24$ gauss, 24 gauss), quite similar to that of the MMA propagating radical. ${ }^{12}$ The signal was observed even at $0^{\circ} \mathrm{C}$, indicating a higher stability of the radical. The $\mathrm{BuMgCl} / \mathrm{Et}_{2} \mathrm{O}-\mathrm{MMA}$ system showed no ESR signals. Therefore, there is some possibility of a radical or coordinated radical mechanism for polymerization with the de-etherated initiator. However, such a radical mechanism should not be of great importance, since the radical concentration was estimated to be $1 \times 10^{-8} \mathrm{~mol}^{-1}$ at most. An extensive study is now under way along with an NMR study on the structure of the initiators, and the results will be published in the near future.

\section{REFERENCES}

1. B. O. Bateup and P. E. M. Allen, Eur. Polym. J., 13, 761 (1977).

2. P. E. M. Allen and B. O. Bateup, Eur. Polym. J., 14, 1001 (1978).

3. P. E. M. Allen, J. Macromol. Sci., Chem., A14, 11 (1980).

4. P. E. M. Allen, M. C. Fisher, C. Mair, and E. H. Williams, "Anionic Polymerization: Kinetics, Mechanisms, Synthesis," J. E. McGrath, Ed., American Chemical Society Symposium Series, No. 166, 1981, p 185.

5. K. Matsuzaki, H. Tanaka, and T. Kanai, Makromol. Chem., 182, 2905 (1981).

6. K. Hatada, T. Kitayama, H. Sugino, M. Furomoto, and H. Yuki, "Preparation and Properties of Stereoregular Polymers," R. W. Lenz and F. Ciardelli, Ed., 1979, p 185.

7. P. E. M. Allen, C. Mair, M. C. Fisher, and E. H. Williams, J. Macromol. Sci., Chem., A17, 61 (1982).

8. T. Miyamoto and H. Inagaki, Polym. J., 1, 46 (1970).

9. S. C. Watson and J. F. Eastham, J. Organometal. Chem., 9, 165 (1967).

10. K. Hatada, T. Kitayama, S. Okahata, and H. Yuki, Polym. J., 13, 1045 (1981).

11. K. Hatada, K. Ute, and T. Kitayama, unpublished results.

12. M. Kamachi, Y. Kuwae, S. Nozakura, K. Hatada, and H. Yuki, Polym. J., 13, 919 (1981). 